\title{
Spectroscopy: Between Modeling, Simulation and Practical Investigation
}

\section{Tawfik A. Saleh}

Department of Chemistry, King Fahd University of Petroleum \& Minerals, Dhahran, Saudi Arabia. Email: tawfikas@hotmail.com

Received December $20^{\text {th }}, 2013$; revised January $22^{\text {nd }}, 2014$; accepted January $27^{\text {th }}, 2014$

Copyright (C) 2014 Tawfik A. Saleh. This is an open access article distributed under the Creative Commons Attribution License, which permits unrestricted use, distribution, and reproduction in any medium, provided the original work is properly cited. In accordance of the Creative Commons Attribution License all Copyrights (c) 2014 are reserved for SCIRP and the owner of the intellectual property Tawfik A. Saleh. All Copyright (C 2014 are guarded by law and by SCIRP as a guardian.

\section{Dear Editor,}

Spectral Analysis Review is an international journal dedicated to the latest advancement of all areas of spectroscopy. The primary goal of this journal is to provide a plat-form for scientists and academicians all over the world to provide, share and discuss various new issues and developments in different aspects of spectroscopy. It aims to determine the state-of-the art and advances progress in the field of spectroscopy and get through its developments.

I have reviewed the literature regarding spectroscopy. Most of the scientific reports recommend that more spectroscopic investigation should be on modeling and simulation, in addition to the spectroscopic properties of nanomaterials [1-4]. I would like to stress that modeling and simulation related work would not only promote understanding the spectroscopic properties of materials and nanomaterials but also enhance more bringing their applications to life. In the same way, coupling modeling and computational studies with nanotechnology will help to develop the designing of nanomaterials with required spectroscopic properties. More interesting is the research related to real applications or models. Examples are; spectroscopic characterization of vibrational modes in artificially designed DNA [5], nonlinear optical spectroscopy for biomolecular structure at solid-liquid interfaces [6], modeling and spectroscopic evidence of antimony adsorption on iron-oxide-rich red earth soils [7], single-molecule studies of intrinsically disordered proteins [8], spectroscopic study of model amyloid $\beta$-peptide oligomers [9] and other directions [10-13].

The editors will always be pleased to receive the following types of inputs or submissions, among others: 1) Research Highlight articles-generally substantial, current review articles that can be expected to be of interest to the spectroscopy community, 2) Research Notes-research announcements, 3) News and Views, and "In Brief" items-announcements and news items, and 4) Meeting announcements, meeting reports and book reviews.

On the side of education, as a community, we need to assess our strategy for teaching and maintaining interest in the field of spectroscopy. Spectroscopic research is rapidly changing and evolving, and it presents many opportunities. Many education innovators may embrace the advancements and examine the rebooting of the academy through a collection of essays. These may explore how to implement new approaches to teaching and research with the use of digital tools; ensure access to lessons and lectures; and take the class time to the high level of interactivity.

Happy Reading.

\section{REFERENCES}

[1] S. Dhar, D. K. Rana, A. Pal and S. C. Bhattacharya, "Photobehavior and Docking Simulations of Drug within Macromolecules: Binding of an Antioxidative Isoquinolindione to a Serine Protease and Albumin Proteins," Journal of Photochemistry and Photobiology B: Biology, Vol. 129, 2013, pp. 69-77. http://dx.doi.org/10.1016/j.jphotobiol.2013.09.007

[2] D. Ray, B. K. Paul and N. Guchhait, "Differential Binding Modes of Anti-Cancer, Anti-HIV Drugs Belonging to Isatin Family with a Model Transport Protein: A Joint Refinement from Spectroscopic and Molecular Modeling Approaches," Journal of Photochemistry and Photobiology B: Biology, Vol. 127, 2013, pp. 18-27. http://dx.doi.org/10.1016/j.jphotobiol.2013.09.007

[3] W.J. Hua, J. D. Biggs, Y. Zhang, D. Healion, H. Ren and S. Mukamel, "Multiple Core and Vibronic Coupling Effects in Attosecond Stimulated X-Ray Raman Spectroscopy," Journal of Chemical Theory and Computation, Vol. 9, No. 12, 2013, pp. 5479-5489. 
http://dx.doi.org/10.1021/ct400767g

[4] A. J. Gesquiere, "Optical Properties and Spectroscopy of Nanomaterials," Journal of the American Chemical Society, Vol. 132, No. 10, 2010, pp. 3637-3638. http://dx.doi.org/10.1021/ja101350v

[5] I. Sizov, M. Rahman, B. Gelmont, M. L. Norton and T. Globus, "Sub-THz Spectroscopic Characterization of Vibrational Modes in Artificially Designed DNA Monocrystal,” Chemical Physics, Vol. 425, 2013, pp. 121-125. http://dx.doi.org/10.1016/j.chemphys.2013.08.015

[6] S. Roy, P. A. Covert, W. R. FitzGerald and D. K. Hore, "Biomolecular Structure at Solid-Liquid Interfaces as Revealed by Nonlinear Optical Spectroscopy,” Chemical Reviews, 2014. http://dx.doi.org/10.1021/cr400418b

[7] M. Vithanage, A. U. Rajapaksha, X. M. Dou, N. S. Bolan, J. E. Yang and Y. S. Ok, "Surface Complexation Modeling and Spectroscopic Evidence of Antimony Adsorption on Iron-Oxide-Rich Red Earth Soils,” Journal of Colloid and Interface Science, Vol. 406, 2013, pp. 217-224. http://dx.doi.org/10.1016/j.jcis.2013.05.053

[8] M. Brucale, B. Schuler and B. Samorì, "Single-Molecule Studies of Intrinsically Disordered Proteins,” Chemical Reviews, 2014. http://dx.doi.org/10.1021/cr400297g

[9] J. Xu, J. Z. H. Zhang and Y. Xiang, "Molecular Dynamics Simulation and Computational Two-Dimensional Infrared Spectroscopic Study of Model Amyloid $\beta$-Peptide Oligomers," The Journal of Physical Chemistry A, Vol. 117, No. 29, 2013, pp. 6373-6379. http://dx.doi.org/10.1021/jp403748z

[10] L. M. da Costa, S. R. Stoyanov, S. Gusarov, P. R. Seidl, J. W. M. Carneiro and A. Kovalenko, "Computational Study of the Effect of Dispersion Interactions on the Thermochemistry of Aggregation of Fused Polycyclic Aromatic Hydrocarbons as Model Asphaltene Compounds in Solution,” The Journal of Physical Chemistry A, Vol. 118, No. 5, 2014, pp. 896-908. http://dx.doi.org/10.1021/jp408005h

[11] K. T. Cheung, Y. Foo, C. H. To and J. A. Zapien, “Towards FDTD Modeling of Spectroscopic Ellipsometry Data at Large Angles of Incidence,” Applied Surface Science, Vol. 281, 2013, pp. 2-7.

http://dx.doi.org/10.1016/j.apsusc.2012.12.144

[12] S. Jana, S. Dalapati, S. Ghosh and N. Guchhait, "Binding Interaction between Plasma Protein Bovine Serum Albumin and Flexible Charge Transfer Fluorophore: A Spectroscopic Study in Combination with Molecular Docking and Molecular Dynamics Simulation,” Journal of Photochemistry and Photobiology A: Chemistry, Vol. 231, No. 1, 2012, pp. 19-27. http://dx.doi.org/10.1016/j.jphotochem.2011.12.002

[13] M. Memarpoor-Yazdi and H. Mahaki, "Probing the Interaction of Human Serum Albumin with Vitamin B2 (Riboflavin) and l-Arginine (l-Arg) Using Multi-Spectroscopic, Molecular Modeling and Zeta Potential Techniques," Journal of Luminescence, Vol. 136, 2013, pp. 150-159. http://dx.doi.org/10.1016/j.jlumin.2012.11.016 